\title{
Wrażliwość jako przedmiot refleksji pedagogicznej
}

\section{Sensitivity as a Subject of Pedagogical Reflection}

\begin{abstract}
ABSTRAKT
Celem artykułu jest namysł nad wrażliwościq człowieka i jej rozumieniem, jak również nad znaczeniem kształtowania wrażliwości dla jakości codziennego funkcjonowania. Problemem badawczym jest pytanie: Jakie jest oblicze wrażliwości człowieka? Struktura artykułu składa się z trzech części: teoretycznej i empirycznej charakterystyki wrażliwości oraz praktycznego wymiaru jej kształtowania w procesie wychowania.

Teoria wrażliwości ma charakter interdyscyplinarny. W rozumieniu wrażliwości wyróżniono cztery komponenty: poznawczy, emocjonalny, działaniowy i moralny. Funkcję zintegrowania poszczególnych aspektów rozumienia wrażliwości przypisano teorii pedagogicznej. Badania empiryczne dotyczqce wrażliwości ukierunkowane sq na jej zdiagnozowanie oraz szukanie zwiq̨zów z innymi zjawiskami. Konstruowane sq skale do pomiaru wrażliwości dzieci, młodzieży i człowieka dorosłego. Wskazano przykłady prac badawczych polskich i zagranicznych uczonych. Empiryczna charakterystyka wrażliwości wskazuje ja jako fenomen, który może być traktowany jako zasób służq̨cy sprawnemu funkcjonowaniu człowieka w życiu codziennym. Wnioski z teoretycznej i empirycznej charakterystyki wrażliwości potraktowano jako istotnq przesłankę kształtowania wrażliwości
\end{abstract}

SLOWA KLUCZOWE

wrażliwość, wrażliwość poznawcza, wrażliwość emocjonalna, nadwrażliwość, niewrażliwość, cnota, wychowanie

\section{KEYWORDS}

sensitivity, cognitive sensitivity, emotional sensitivity, hypersensitivity, insensitivity, virtue, upbringing

SPI Vol. 23, 2020/4

ISSN 2450-5358

e-ISSN 2450-5366 DOI: 10.12775/SPI.2020.4.007

Nadestano: 29.06.2020 Zaakceptowano: 06.10.2020

Miscellanea 
w procesie edukacji i wychowania. Stanowiq one część trzeciq artykułu i mogq być wykorzystane do kreowania i korygowania prakłyki wychowania.

W tekście potraktowano wrażliwość jako silnq stronę człowieka (cnotę), którq można i należy kształtować w procesie wychowania. Jest ona niezbędna do kształtowania pozytywnych relacji intrapersonalnych $i$ interpersonalnych. Dewaluowanie wrażliwości można uznać za wskaźnik swoistego regresu człowieczeństwa.

\section{ABSTRACT}

The goal of the article is to dwell upon sensitivity, its comprehension and meaning in shaping sensitivity for the quality of everyday functioning. The research matter is to define whether the face of human sensitivity has a positive or negative output. The structure of the article contains three parts: theoretical, empirical characteristics of sensitivity and its practical aspect of its shaping in upbringing process.

The theory of sensitivity has an interdisciplinary character. In the full meaning of sensitivity, four components are pointed out: cognitive, emotional, acting and moral. The function to integrate the various aspects of understanding the sensitivity is delegated to pedagogical theory. The empirical research considering sensitivity are heading towards its diagnosis and searching for relations with other phenomena. The scales of sensitivity levels are constructed for children, adolescents and adults. The examples of polish and foreign scientists are provided. The empirical characteristics of sensitivity reveals it as a phenomenon which is a resource for flawless human functioning in everyday life. The conclusions from theoretical and empirical characteristics of sensitivity has been treated as grounds for designing sensitivity in the processes of education and upbringing. The abovestand for a third part of the article and can be used for creating and adjusting the upbringing practice.

In the article an anxiety of the world without sensitivity is expressed. The sensitivity is treated as a strong side of human (virtue) which can and needs to be shaped in the process of upbringing. It is inevitable for creating positive intrapersonal and interpersonal relations. Diminishing the meaning of sensitivity can be defined as an indicator for humanity regress. 


\section{Wprowadzenie}

Wrażliwość jest pięknym przymiotem ludzkiej uczuciowości. Piękno to kształtowane jest wartością wrażliwego bycia: dzięki niemu potrafimy być dla innych, a nie tylko dla siebie. Wrażliwość jest obecna w szeregu twórczych aktywności, począwszy od stanu zwanego natchnieniem, poprzez rozwój kreatywności i kończąc na motywowaniu oraz wyzwalaniu siły do działania. W zasadzie nie należałoby tutaj wskazywać kresu, ponieważ radość tworzenia nie uznaje ograniczeń (Koberda 2005).

Piękno wrażliwości ma też drugie oblicze. Może być niszczące, jeśli jest pozostawione samo sobie. Odsłania osobę przed innymi, narażając ją na zranienia; męczy głębią i wielością dostrzeganych i przeżywanych bodźców; wprowadza niepewność przy rozważaniu dylematów i niezdecydowanie przy podejmowaniu decyzji, utrudniając lub uniemożliwiając sprawne działanie. $W$ potocznym odbiorze wrażliwość jest mylona z psychiczną słabością, emocjonalną niestabilnością czy nawet $\mathrm{z}$ formą niedojrzałości. Wrażliwość pociąga za sobą konieczność podlegania cierpieniu (Baczko 1964: 328). Jednak znakomity reportażysta Ryszard Kapuściński uznał ją za istotny element aksjologicznego porządku świata. Napisał w Lapidariach następująco: „Boję się świata bez wartości, bez wrażliwości, bez myślenia. Świata, w którym wszystko jest możliwe. Ponieważ wówczas najbardziej możliwe staje się zło" (Kapuściński 2007: 323). Problemem badawczym staje się więc pytanie: Jakie jest oblicze wrażliwości człowieka?

Namysł nad kategorią wrażliwości podejmowany jest stosunkowo rzadko w dyskursie pedagogicznym. Tymczasem, właśnie wychowanie i samowychowanie są procesami, w których jest przestrzeń na kształtowanie wrażliwości. Mądrościowe traktowanie wrażliwości wpisuje się w całościowy rozwój osoby. Nieumiejętne postępowanie z nią prowadzi do utraty wewnętrznej równowagi, co skutkuje dysharmonią zewnętrzną w relacjach społecznych. To człowiek decyduje o miejscu i znaczeniu wrażliwości w jego psychofizycznej kondycji, dlatego powinien być do tego przygotowany.

W niniejszym artykule podzielona zostaje obawa przed istnieniem świata bez wrażliwości. Przedmiotem tego tekstu jest wrażliwość, potraktowana jako silna strona człowieka, którą można i należy kształtować w procesie wychowania. Co więcej, jest ona niezbędna 
do kształtowania pozytywnych relacji intrapersonalnych i interpersonalnych. Dewaluowanie jej można uznać za wskaźnik swoistego regresu człowieczeństwa. Celem artykułu jest namysł nad rozumieniem wrażliwości człowieka i znaczeniem jej kształtowania dla jakości codziennego funkcjonowania. Realizacja tego celu wymaga analizy literatury przedmiotu, w której jest zawarta siła teorii inspirującej interpretację oraz dogłębność empirii kreująca i korygująca praktykę. Wyznaczają one strukturę artykułu ze wskazaniem na teoretyczną i empiryczną charakterystykę wrażliwości oraz wymiar praktyczny jej kształtowania w procesie wychowania.

\section{Teoretyczna charakterystyka wrażliwości}

Teoria wrażliwości ma charakter interdyscyplinarny. W interpretacji rozumienia i wartości wrażliwości uwzględniono przesłanki nauk humanistycznych i społecznych, choć zainteresowanie nią dotyczy także innych nauk, np. medycznych czy sztuki. Uwzględnienie przesłanek teoretycznych różnych nauk składa się na pełne rozumienie pojęcia wrażliwości, w którym można wyróżnić kilka komponentów: teoria filozoficzna podkreśla znaczenie komponentu poznawczego wrażliwości, psychologiczna - komponentu emocjonalnego, socjologiczna - działaniowego. Komponenty te wzajemnie przenikają się, dlatego teorii pedagogicznej przypisano funkcję zintegrowania poszczególnych aspektów rozumienia wrażliwości, ze szczególnym uwzględnieniem komponentu moralnego.

\section{Komponent poznawczy}

Nie da się zrozumieć człowieka bez wrażliwości. Tak istotne znaczenie wyjaśnieniu wrażliwości przypisywane jest na gruncie filozofii. Francuski filozof okresu oświecenia Denis Diderot uznał, że wrażliwość jest matką człowieczeństwa i sprawia, że osoby wrażliwe „istnieją bardziej” (por. Markowski 2013: 222). To egzystencjalne określenie wyraźnie koreluje z twierdzeniem współczesnej filozof Barbary Skargi, że wrażliwość stanowi immanentną składową tożsamości, pogłębiającą ludzkie istnienie (Skarga 1997: 152). Anna Kamińska uznała wrażliwość za źródło rozumu, uzasadniając tę tezę wypowiedziami znanych filozofów: 
Można zatem uznać, iż świadomość ludzka, a za nią także myślenie i rozumienie, jest jakąś formą wrażliwości. To dlatego Pascal może mówić o „nierozumie ludzi obojętnych” (Pascal 2008: 115), a Jaspers o „doznaniu zrozumienia i niezrozumienia z drugim człowiekiem” (Jaspers 1993: 122) albo o „doświadczaniu współmyśleniem” (Jaspers 1993: 129). Z. Cackowski nazywa tego typu wrażliwość poznawczą „czujnością lękową", uznaje bowiem, że rzeczywista świadomość jest i nie może nie być obciążona bólem, poczuciem zagrożenia i lękiem. Zwraca przy tym uwagę na znaczenie francuskiego słowa appréhension - obawa, bojaźń, lęk, ale także ujęcie, schwytanie, pojęcie, zdolność pojmowania, zrozumienie. Wskazuje ono na zasadniczą więź między lękiem a świadomością, pojmowaniem, pojęciem. Rozumienie (świadomość) świata, życia, ludzi wyrasta z lęku jako jego negacja i przezwyciężanie. Wrażliwość lękowa okazuje się źródłem wysiłku zmierzającego w stronę poznania, napędem działań transcendujących, i w tym sensie jest ona źródłem rozumu ludzkiego. Jest ona także koniecznym warunkiem trwania i przetrwania w świecie, zwłaszcza w „bólogennym” świecie „płynnej ponowoczesności”, który wymaga szczególnie natężonej czujności (Kamińska 2006/2007: 45-46).

$\mathrm{Na}$ podstawie przytoczonej myśli można by uznać, że to specyficzny aspekt wrażliwości, tzw. wrażliwość negatywna, jest źródłem rozumu ludzkiego. Dalszy wywód podważa jednak takie myślenie:

Geneza ludzkiej rozumności ma również swój wątek pozytywny. Prowadzi poprzez przyjemność, rozkosz, zadowolenie, satysfakcję, szczęście oraz nadzieję i oczekiwanie ich powtórzenia. Świadomość to czujność bólu i lęku, ale także radości i nadziei. Ludzka rozumność nie może istnieć ani tam, gdzie pewność sukcesu, ani tam, gdzie absolutna bezsilność i rozpacz (Kamińska 2006/2007: 46).

Wrażliwość jest więc specyficzną dyspozycją poznawczą człowieka, której znaczenie wzrasta w dobie technicyzacji i nadmiaru informacji oraz opierania związków miłości i przyjaźni na egoistycznej korzyści zamiast na wzajemnym, bezinteresownym spełnianiu się w nich. Filozoficzna interpretacja wrażliwości podkreśla jeden z jej istotnych komponentów - poznawczy - znosząc charakterystyczną opozycyjność tradycyjnego myślenia, że coś jest albo rozumowe, albo uczuciowe. Tę alternatywę wyrażają trafnie słowa Blaise'a Pascala:

Ludzie, którzy nawykli sądzić czuciem, nie pojmują zgoła procesu rozumowania; chcą od razu ogarnąć rzecz jednym spojrzeniem i nie są przyzwyczajeni do szukania zasad. Drudzy, przeciwnie, przyzwyczajeni rozumować na podstawie zasad, nie pojmują zgoła spraw uczucia (Pascal 2008: 30). 
Tymczasem, racjonalność nie musi wykluczać emocji. Są one przecież jednym z elementów motywacyjnych działania. Wrażliwość jest więc źródłem ludzkiego rozumu i czynnikiem motywacji poznawczej.

\section{Komponent emocjonalny}

Aspekt emocjonalny wrażliwości podkreślany jest na gruncie psychologii. Zdolność przeżywania bodźców jest podstawową definicją wrażliwości (por. Chojnacka 2018: 114). Wyróżniana jest prosta wrażliwość zmysłowa, będąca reakcją organizmu na bodźce świata zewnętrznego, oraz wrażliwość „wyższego rzędu”, związana z procesami myślowymi i emocjonalnymi (Przybylski 1978: 48). Kazimierz Dąbrowski zwrócił uwagę, że poszczególne osoby inaczej reagują na zewnętrzną i wewnętrzną stymulację bodźcami (Dąbrowski 1975), co wskazuje na indywidualne zróżnicowanie wrażliwości. Można więc wyrazić ją w kategorii cechy podmiotowej o zróżnicowanym nasileniu. Na dwuznaczność pojmowania tej cechy, jako pasywnej bądź aktywnej, zwróciła uwagę kulturoznawczyni Marta Rakoczy:

Słownik języka polskiego waha się między traktowaniem jej jako pozytywnej jakości związanej ze „zdolnością przeżywania wrażeń, emocji, czułością, uczuciowością” a rozumieniem jej jako „podatności na coś, braku odporności" (Uniwersalny stownik języka polskiego PWN 2003: 508). W tym pierwszym znaczeniu raz traktuje ją jako cechę wrodzoną organizmu, a innym razem jako możliwość, a nawet umiejętność o charakterze intencjonalnym, nieredukowalną do tego, co naturalnie dane. Ta semantyczna dwuznaczność powoduje, że wrażliwość może być rozumiana dwojako. Zgodnie z pierwszą definicją jest ona zdolnością polegającą na pasywnym narażaniu się na określone impulsy z zewnątrz. Drugie znaczenie definiuje ją jako aktywną umiejętność, związaną nie tyle z odczuwaniem bodźców, ile $\mathrm{z}$ ich poszukiwaniem; $\mathrm{z}$ twórczą (a nie reaktywną) postawą względem przeżywanego doświadczenia. [...] Wspomniana dwuznaczność w jej pojmowaniu (jako cechy pasywnej bądź aktywnej) i związane $z$ nią kulturowe konceptualizacje podmiotu wrażliwego towarzyszą wielu nowoczesnym projektom, mającym - moim zdaniem fundamentalny wpływ na zachodnią, w tym polską, współczesność (Rakoczy 2018: 141).

Rozumienie wrażliwości jako cechy podmiotowej bywa zawężane w związku z płcią. Uznaje się, że wrażliwość stanowi zespół cech „typowo kobiecych” obok opiekuńczości, czułości czy zmienności. 
W tym przypadku „wrażliwość przedstawicielek płci pięknej nie stanowi [...] ich przymiotu, lecz jedynie pożądaną właściwość, bez której ich kobiecość staje się wątpliwa” (Szpunar 2017: 130). Jednak nie każda współczesna kobieta akceptuje tradycyjne postrzeganie atrybutów kobiecości, modyfikując je przejmowaniem elementów specyficznych dla męskiego stylu bycia, co może się wiązać ze świadomym zatracaniem wrażliwości. Warto zauważyć, że konsekwencje takiego wyboru dotyczą nie tylko zewnętrznych oznak kobiecości, skoro uznaje się, że wrażliwość „decyduje o jakości kontaktów międzyludzkich i jest świadectwem pełnego rozwoju człowieka” (Błaszczyk 2010: 95). Jej zatracanie jest więc równoznaczne z niszczeniem w sobie człowieczeństwa. Wniosek ten odnosi się do człowieka bez względu na jego płeć.

Człowiek żyje w świecie, odbiera bodźce zewnętrzne oraz wewnętrzne i różnie na nie reaguje, nawiązując relacje ze światem i kształtując swój sposób bycia. Takim bodźcem mogą być na przykład wartości. Ustosunkowanie się wobec nich „dookreśla” człowieka w jego myśleniu i działaniu. W sposób bycia wpisana jest także wrażliwość jako umiejętność odczuwania tego, co dociera do człowieka jako bodziec. $\mathrm{W}$ relacji $\mathrm{z}$ drugim człowiekiem nabiera ona szczególnego wymiaru jako współrozumienie i współodczuwanie tego, kim jest się dla tej osoby i kim ona jest dla mnie. Można więc przyjąć, że wrażliwość związana jest ze współbyciem osób. Oznacza specyficzne otwarcie się na drugą osobę, przez co człowiek daje poznać siebie i sam poznaje drugiego. Wrażliwość poprzedza poznanie: „Najpierw jest wrażliwość, potem zaś przychodzi poznanie, które nie może się do wrażliwości nie odwołać. Kiedy natomiast wrażliwość zostaje wykluczona, poznanie nie ma się na czym oprzeć" (Markowski 2010: 104). Specyfika tego otwarcia wyraża się w radykalności i ryzykowności. Jest ono przepełnione szczerością i zaufaniem, ale człowiek może też doświadczyć zranienia (Jędraszewski 1994: 154). Jednak „im dłużej znam daną osobę, tym bardziej uwrażliwiam się na nią" (Chojnacka 2018: 123). Można więc dogłębniej poznać i zrozumieć jej zachowania, a nawet w swojej wrażliwości je przeczuwać. Nie można jednak, nawet przy wysokiej wrażliwości, tak „przeniknąć” osoby, by przestała być dla nas tajemnicą. Jeśli miłość jest bezinteresowną troską o dobro drugiej osoby, to wrażliwość jest umiejętnością niezbędną do kształtowania takiej relacji. Miłość „to relacja bycia ze 
sobą, troski i współczucia” (por. Chojnacka 2018: 123). Uwrażliwianie się nawzajem na siebie to budowanie wspólnej przestrzeni objętej zatroskaniem. Może taką właśnie formę wspólnego czuwania miał na myśli Heraklit z Efezu, stwierdzając: „Czuwający mają świat wspólny, śpiący są odwróceni do swych osobnych światów” (Heraklit 1992: 9).

Psychologiczna teoria wrażliwości wskazuje dwojaką naturę zjawiska. Z jednej strony dostarcza podstawowego, najbardziej prostego wyjaśnienia wrażliwości jako reakcji na bodziec. Zatrzymanie się na tym poziomie rozumienia oznaczałoby jednak, że stan braku wrażliwości (poza stanem chorobowym) nie jest możliwy, ponieważ człowiek jest tak uwikłany w rzeczywistość, że zawsze odbiera jakieś bodźce. $Z$ drugiej strony obserwacja życia społecznego przynosi dowody o zróżnicowanym nasileniu (również o braku) wrażliwości osób wobec tej samej sytuacji. Podstawowa definicja wrażliwości wymaga więc nadbudowania, ponieważ kreowanie i korygowanie świata relacji, zwłaszcza intrapersonalnych i interpersonalnych, wymaga różnych sposobów bycia: odczuwania i współodczuwania, przeżywania i współprzeżywania, zatroskania i miłości. Wrażliwość naturalnie dana jako cecha może więc być pojmowana także jako umiejętność, której treść i nasilenie mogą być kształtowane w pracy wychowawczej i samowychowawczej.

\section{Komponent działaniowy}

Socjolog Theodor Adorno uznał, że wyostrzona wrażliwość „rozjaśnia” każde zjawisko społeczne (Adorno 1984: 5). Na gruncie socjologii wrażliwość zyskuje naturę dyskursywną, co oznacza, że pojęcie to jest kształtowane przez kontekst kulturowo-społeczny. Przejawia się ona w sposobach używania języka, przekazywanych ideach i interakcjach społecznych (Stoch 2016: 131). W takim ujęciu wrażliwość jest kompetencją społeczno-kulturową, która kształtuje wyobraźnię społeczną i manifestuje swoją obecność lub jej brak konkretnymi działaniami w przestrzeniach kulturowych: „Wrażliwość jest kompetencją społeczną i kulturową, a nie esencjalną cechą przypisaną człowiekowi a priori. Wrażliwości uczymy się $\mathrm{w}$ procesach socjalizacji. Jednostki pozbawione tego typu «treningu wrażliwości» nie potrafią dostosować się do istniejących norm społecznych" (Stoch 2016: 131). Zdaniem zacytowanej autorki pojęcie 
wrażliwości dotyczy relacji większość-mniejszość, silny-słaby, dominacja-uległość (Stoch 2016: 131). Socjologiczna teoria wrażliwości sytuuje więc zjawisko na kontinuum nasilenia, o którym decyduje wiele czynników.

Aspekt relacyjności i działania podkreślony jest też w ujmowaniu wrażliwości jako postawy wobec zamierzeń, uczuć i czynów własnych oraz innych osób. Postawa taka opiera się na odpowiedzialności, uczciwości i sprawiedliwości, a kierowanie się tymi wartościami jest podyktowane empatią, troską i życzliwością (por. Klimaszewska 2008: 70). Postawę i działanie osoby wrażliwej można scharakteryzować na przykładzie opuszczania bezpiecznej kryjówki, korzystając z obrazów przedstawionych przez Antoniego Kępińskiego oraz Józefa Tischnera. Naukowiec i lekarz psychiatrii aksjologicznej, Antoni Kępiński, napisał:

Współczesne warunki naszej cywilizacji utrudniają przyjęcie odpowiedzialności za siebie i za otoczenie, utrudniają też wyładowanie tendencji twórczych, postawa konsumpcyjna wyraźnie przeważa nad postawą twórczą, wreszcie negatywny nieraz stosunek uczuciowy do otaczającego świata powoduje, że „biorę” przeważa nad „daję”. Człowiek nie jest skłonny do obdarzania uczuciami pozytywnymi świata, który jest mu obojętny, a nawet wrogi (Kępiński 1977: 155).

Józef Tischner zauważył, że świat z jego wojnami i zbrodniami zawsze był dla rozumnego człowieka źródłem lęku. Problem jest w tym, jak ten lęk pokonać i właśnie ta propozycja współczesnej cywilizacji nie jest jasna:

Metoda mnożenia władania nad człowiekiem kwestionuje jego wolność, jego wierność, jego poczucie godności. Człowiek „posiadany” jest już człowiekiem utraconym. Jego bliskość nie daje szczęścia, lecz napawa goryczą i wtrąca w beznadzieję. Mamy wprawdzie w pobliżu człowieka, ale czy potrafimy powiedzieć, po co go mamy? Im bardziej posiada się człowieka, tym trudniejsza do pokonania ściana dzieli bliskich posiadanych od bliskich posiadających (Tischner 2011: 464).

Zasadnicze pytanie natury socjologicznej dotyczy tego, czy wspó1czesna kultura daje propozycje rozwiązania. Trudno jest jednoznacznie odpowiedzieć na to pytanie, natomiast lektura zacytowanych dwóch dzieł jest przesłanką do tego, by stwierdzić, że współczesna kultura może być źródłem takiej nadziei pod warunkiem, że nastąpią zmiany w sposobie przeżywania wartości i siebie, a to zadanie dotyczy 
najpierw człowieka, który tworzy kulturę. Sposób doświadczania przez człowieka wartości jest bowiem „miejscem skrzyżowania dróg wiodących bądź w stronę kryjówki, bądź w stronę przestrzeni otwartej nadzieją. W zależności od podjętego wyboru wartości człowiek albo będzie szedł przez życie drogą tworzenia, albo pozostanie przy pewności schronienia” (Tischner 2011: 456). Kryjówka jest miejscem „wolności zalęknionej, wolności zatroskanej potrzebą chronienia siebie. Otwarta przestrzeń nadziei to przestrzeń wolności zatroskanej potrzebą realizowania wartości” (Tischner 2011: 456-457). Kryjówka jest schronieniem bezpiecznym wewnątrz, ale dokoła niej znajduje się przestrzeń możliwych relacji z innymi ludźmi. Osoby „z kryjówek" odnoszą się w specyficzny sposób do przebywania z innymi:

Ktokolwiek znalazł się w polu obcowania z człowiekiem z kryjówki, poczul pod stopami ziemię niepewną; czegoś się tu od niego oczekuje, ale nie wiadomo bliżej czego. Im głębiej wszedł człowiek w swą kryjów$\mathrm{kę,}$ tym ważniejsze stają się dla niego wszelkie spotkania $\mathrm{z}$ innymi, ale też tym bardziej skostniała i trudna do przemienienia jest ich forma. Raz dąży się do zjednania sobie ludzi, to znowu do oddalenia ich od siebie, raz się ich bezpodstawnie oskarża, kiedy indziej przechodzi się do bezpodstawnego oskarżania siebie, jakby się chciało sprowokować uniewinnienie. Wszystko to ma określony cel: człowiek stara się utrzymać drugiego człowieka w bezpiecznym oddaleniu od ściany kryjówki. W tym właśnie celu prowadzi z nim swoistą grę - grę o zawładnięcie. Zawładnięcie jest dla człowieka z kryjówki podstawową formą oswajania bliźniego i świata (Tischner 2011: 457).

Oczekiwana zmiana w sposobie przeżywania wartości i siebie dotyczy wyjścia z kryjówki oraz innego sposobu „oswajania” świata. Tym sposobem jest postawa rozumiejąca, a nie lękowa. Człowiek czuje się dobrze wśród tych, których poznał i zrozumiał, i którzy jego poznali i zrozumieli. To poznanie i zrozumienie zostało poprzedzone wrażliwością. Dla ludzi wrażliwych otaczający ich świat jest tajemnicą, która pociąga i zaprasza do poznania i przyjaźni.

Epoka terroru, przemocy, bezrobocia, głodu czyni świat złowrogim i generuje postawy lękowe, wymuszające walkę lub ucieczkę, by chronić siebie. Wybór: zniszczę lub sam zostanę zniszczony, wymusza uniewrażliwienie się na doznawane bodźce. Osoby lękowe nie potrafią działać w sposób wrażliwy (Szpunar 2018: 21).

Komponent działaniowy ma większe prawdopodobieństwo zaistnienia, jeśli wrażliwość poznawcza i emocjonalna współwystępują. 
Zdarza się, że osoba o wysokiej wrażliwości poznawczej ma deficyt komponentu emocjonalnego i odwrotnie. Funkcje tych komponentów są różne. Dzięki wrażliwości poznawczej „można dostrzec i wyodrębnić elementy, których inni nie dostrzegają, umykające uwadze większości” (Pleszczyński 2018: 96). Wraz z ciekawością i umiejętnością zdumienia, z którymi współwystępuje, różnicuje monotonię tego, co mniej wrażliwym wydaje się nieistotne czy nieciekawe. Wrażliwość emocjonalna natomiast związana jest z decyzjami o bliskości lub odrzuceniu: „Adekwatność emocjonalna polega na umiejętności stosownej do okoliczności oceny własnej postawy wobec innego człowieka oraz zbiorowości i vice versa - postawy innych ludzi i zbiorowości wobec siebie (Pleszczyński 2018: 96). Wrażliwość poznawcza „wymaga aktywności zmysłowej skierowanej na zewnątrz, bo chodzi o poznanie i wiedzę. Wrażliwość emocjonalna jest nastawiona na wnętrze, ma na celu stworzenie więzi, odczuwanie wyjątkowości i niezwykłości sytuacji” (Pleszczyński 2018: 97). Kształtowanie wrażliwości wymaga uwzględnienia każdego komponentu, by nie utrwalać stereotypowego przeciwstawiania racjonalności i emocjonalności życia. Współcześnie szczególnego starania w tym zakresie wymaga wrażliwość emocjonalna. Jak zauważono: „wartości poznawcze podyktowane przez rozum bronią się poprzez prawdę i z tego powodu są - w pewnym sensie - łatwe. Natomiast wartości związane z wrażliwością emocjonalną są trudniejsze, ich rangi nie da się udowodnić przez odwołanie do prawdy" (Pleszczyński 2018: 98).

Wzajemne przenikanie się procesów poznawczych i emocjonalnych daje większe szanse na zaistnienie wrażliwej postawy i konkretnego zachowania. Interpretacja socjologiczna wnosi do rozumienia wrażliwości postrzeganie jej jako pewnego rodzaju aktywności życiowej.

\section{Komponent moralny}

Interesujące ujęcie wrażliwości można znaleźć w rozważaniach cytowanego już francuskiego filozofa Denisa Diderota, dla którego oznacza ona „czułą i delikatną dyspozycję duszy, która sprawia, że łatwo się ona wzrusza i łatwo daje się dotknąć [...]. Dusze wrażliwe istnieją bardziej niż inne: rzeczy dobre i złe mnożą się na ich oczach. Refleksja może stworzyć człowieka rzetelnego, lecz wrażliwość 
stwarza człowieka cnotliwego" (cyt. za: Markowski 2013: 221-222). Myśl ta podkreśla jeszcze jeden komponent wrażliwości: moralny. Wrażliwość nie tylko stwarza człowieka cnotliwego; ją samą można rozpatrywać w kategorii cnoty. Takie zadanie można powierzyć teorii pedagogicznej, która pełni funkcję integrującą wiedzę o wychowaniu człowieka (por. Chodkowska 2008: 47).

Rozpatrywanie wrażliwości w kategorii cnoty ma wyraźne konotacje moralne, ponieważ cnotą jest sprawność wyłącznie moralnie dobra, a jej wyrazem jest działanie moralnie dobre. Jako następstwo usprawnienia w prawości rozumu i woli oraz nastawienia do dokonywania czynów moralnie dobrych, cnota wyraża prawość osoby i jej działania (Jazukiewicz 2012: 174). Poszczególne wymiary wrażliwości można teoretycznie rozdzielać i analizować jako oddzielne komponenty, jednak w rzeczywistości stanowią one całość określającą człowieka w jego sposobie bycia wobec innych i siebie. Kategoria cnoty łączy harmonijne urzeczywistnianie tych wymiarów.

$\mathrm{Na}$ podstawie przedstawionych przesłanek filozoficzno-psychologiczno-socjologicznych można przyjąć, że cnota wrażliwości usprawnia człowieka poznawczo $\mathrm{w}$ doświadczaniu i zrozumieniu świata, życia i ludzi, a także wolicjonalno-emocjonalnie w indywidualnym przeżywaniu tego, co jest doświadczane wraz z odczuwaniem wyjątkowości i niezwykłości sytuacji. Ujawnia się w zachowaniu nieobojętnym wobec tego, co jest doświadczane i przeżywane, ukierunkowanym na tworzenie więzi poznawczej i emocjonalnej. Kształtowanie więzi świadczy o otwartości i pozytywnym nastawieniu osoby, o rozumieniu i współrozumieniu, o odczuwaniu i współodczuwaniu, o przeżywaniu i współprzeżywaniu, czyli specyficznym sposobie bycia, który wyklucza zawładnięcie i posiadanie, natomiast wnosi zatroskanie w budowanie wspólnej przestrzeni. Jest to sposób bycia, który charakteryzuje:

- postawa rozumiejąca i współrozumiejąca, przeżywająca i współprzeżywająca zamiast lękowej;

- otwartość, poznanie i przyjaźń zamiast walki lub ucieczki;

- nastawienie na poznawanie siebie, innych i świata oraz dawanie innym poznać siebie zamiast "chronienia” siebie; to specyficzne „oswajanie” świata przynosi pewność w byciu;

- ciekawość i zdumienie zamiast monotonności i obojętności; 
- uwaga i zauważanie zamiast nieistotności i „umykaniu” czegoś; dostrzeganie niepowtarzalności w miejsce zwyczajności i pospolitości;

- adekwatność oceny własnych zamierzeń, uczuć i zachowań wobec innych oraz postawy innych wobec siebie;

- bliskość zamiast odrzucenia;

- radość i afirmacja zamiast smutku i negacji; nadzieja i tworzenie zamiast pesymizmu i znużenia.

Wrażliwość jako cnota jawi się jako siła człowieka. Jej moc wynika ze sprzyjającego sposobu bycia. Sprzyjanie jest byciem życzliwym dla drugiego, pozwalającym mu pozostawać sobą i realizować siebie. Sprzyjanie przyczynia się do doświadczania radości bycia. Jest w opozycji do „niesprzyjania” jako sposobu bycia, pod wpływem którego drugi człowiek doświadcza smutku egzystencji zamiast rozwoju. Sprzyjająca moc cnoty wrażliwości wyklucza lęk i strach, typowe dla zawładnięcia i posiadania.

Interpretacja wrażliwości w kategorii cnoty znosi dwuznaczność postrzegania wrażliwości i jej skutków: $\mathrm{z}$ jednej strony jako twórczej postawy względem przeżywanego doświadczenia, a z drugiej jako formy słabości i niedojrzałości osoby. Cnota jest kategorią, która ma swoją wartość. Jest nią moralne dobro jako atrybut cnoty. $Z$ tego powodu cnota jest pięknem bycia. Dzięki niej człowiek nie tylko jest, lecz w określony sposób odnosi się do swojego bycia. Odniesienie to charakteryzuje stałe ukierunkowanie osoby na realizację moralnego dobra (Jazukiewicz 2012: 163-164). Jest ono możliwe poprzez usprawnianie rozumu w rozpoznawaniu moralnego dobra, woli w jego wyborze i uczuciowości tak, by umożliwiała emocjonalne odniesienie się do wskazania rozumu i wyboru woli. Jedność działania rozumu, woli i złożonej struktury uczuciowości jest podstawą praktykowania każdej cnoty (Jazukiewicz 2012: 177). Jest też przedmiotem wychowania, które jako proces społeczny dotyczy wzrastania osoby w człowieczeństwie poprzez urzeczywistnianie jej potencjału rozwojowego:

Człowiek doskonali się na miarę swoich możliwości poprzez dobre czyny. Wybiera do realizacji dobro, które odpowiada jego rozumnej naturze. Odpowiedniość ta wyraża się właśnie w tym, że poprzez realizację dobra człowiek moralnie się doskonali: „dobro udoskonala byt” (Wojtyła 1957: 307). Własna doskonałość moralna pozostaje wtórna wobec czynionego dobra (Jazukiewicz 2012: 186). 
Dla kształtowania cnót specyficzna jest harmonia, która wyraża moralne uporządkowanie wewnętrzne (rozumności, wolności i uczuciowości) i zewnętrzne jako swoisty ład działania osoby. Człowiek i jego działanie nabierają przez to mocy jako bycie, którego nie potrzeba zmieniać.

Kształtowanie cnoty wrażliwości wymaga uwzględnienia wszystkich jej komponentów. Stąd zasadność przypisania tej kategorii analizy wrażliwości do teorii pedagogicznej, skoro pełni ona funkcję integrującą wiedzę o wychowaniu człowieka, korzystając z przesłanek teoretycznych i empirycznych innych nauk. Chodzi o takie rozumienie i kształtowanie wrażliwości w praktyce, by stanowiła ona mocną stronę człowieka w kształtowaniu relacji ze światem i własnego sposobu bycia. Kategoria cnoty rozstrzyga o pozytywnym obliczu wrażliwości. Zrozumiałe stają się wtedy wypowiedzi o wrażliwości jako matce człowieczeństwa, umiejętności niezbędnej do kształtowania relacji miłości, czy też dotyczące obawy przed światem pozbawionym wrażliwości, gdyż staje się on wówczas przestrzenią dla zła. Kategoria cnoty wnosi do interpretacji wrażliwości wymiar etyczny, wiążąc ją z moralnym dobrem osoby i jej działania. Proces wychowania zawsze jest procesem etycznego zaangażowania. Podejmowany jest wobec drugiej osoby, dla jej dobra i w poczuciu odpowiedzialności za nią. Działania wychowawcze mają na celu dobro indywidualne wychowanka i dobro społeczne. Wrażliwość nie jest zwróconą tylko ku sobie umiejętnością i refleksją. Gdyby tak było, wtedy mogłaby przybrać formy lękowe i inne, destrukcyjne dla osoby. Jako cnota jest sprawnością o charakterze intra- i interpersonalnym: dostrzeganie, odczuwanie, rozumienie i przeżywanie ma dwa kierunki: dotyczy siebie i innych. Cnota nie jest bowiem ozdobą człowieka, lecz wartościowym sposobem odniesienia się do świata, innych i siebie.

Cnota sytuuje się pomiędzy dwiema skrajnościami. Jedna z nich jest nadmiarem, a druga niedomiarem cnoty. Na przykład nadmiarem odwagi jest zuchwalstwo, a niedomiarem tchórzostwo. Cnota wrażliwości również usytuowana jest pomiędzy przeciwieństwami. Jej nadmiarem jest nadwrażliwość. W literaturze przedmiotu używane są także określenia osoby wysoko wrażliwej, wyjątkowo wrażliwej, ponadprzeciętnie wrażliwej, wysoko reaktywnej czy nadwydajnej mentalnie (por. Zeff 2008; Sand 2016; Kabzińska 2017; Aron 2018; Petitcollin 2019). Naukowiec i psychoterapeutka Elain N. Aron na 
podstawie wieloletnich badań dała naukowe podstawy temu zjawisku. Teorię przedstawiła w książce Wysoko wrażliwi. Jak funkcjonować w świecie, który nas przyttacza (2018). Jej zdaniem, osoby wysoko wrażliwe dostrzegają wiele niuansów, które umykają innym. Idzie to $\mathrm{w}$ parze z ostrożnością, wycofaniem i potrzebą spędzania dodatkowego czasu w samotności. Postrzegane są przez to jako nieśmiałe, zalęknione, słabe, a nawet nietowarzyskie. Chcąc uniknąć tych etykiet, starają się być takie, jak inni, ale skutkuje to nadpobudzeniem i przeciążeniem, przez co z kolei zapracowują na opinię znerwicowanych i „nienormalnych” najpierw w cudzych oczach, a następnie we własnych. Te i inne doświadczenia są stresujące. Jest ich wiele, ponieważ wysoka wrażliwość powoduje silniejszą reakcję na bodźce w porównaniu $\mathrm{z}$ innymi osobami. Jeśli osoba uzna taką reakcję za swoją słabość, poziom stresu dodatkowo wzrasta. Następnie pojawia się poczucie beznadziejności i bezwartościowości (Aron 2018: 56-58). Wysoka wrażliwość prowadzi do nadpobudzenia i jest niezaprzeczalnie kłopotliwa. Osoba czuje się pozbawiona kontroli nad sobą, co uniemożliwia optymalne działanie (Aron 2018: 67). Trudno jest jej odróżnić to, co istotne, od tego, co zupełnie nie ma znaczenia. $Z$ wysoką wrażliwością można jednak się nauczyć żyć, ponieważ terapeuci wskazują jej pozytywne strony i sposoby radzenia sobie z przestymulowaniem. Nie można więc tej formy nadwrażliwości potraktować jako wady, tym bardziej, że bywa nazywana cnotą: „Jest to dziwna cnota, ale wciąż jest ona darem. W końcu wysoka wrażliwość daje szansę na głębsze spojrzenie na rzeczywistość” (https://pieknoumyslu.com/ cytaty-dla-osob-wrazliwych/ [dostęp: 4.06.2020]). Nie można tego powiedzieć o innych formach nadmiaru wrażliwości: przewrażliwieniu i drażliwości. Mają one konotacje wyłącznie negatywne. Przewrażliwienie może być następstwem bezmyślności, ale częściej jest dowodem samolubstwa - może dotyczyć własnej urody, umiejętności, wiedzy, posiadanych rzeczy materialnych. Osoba jest nadmiernie wyczulona na krytykę, której nie przyjmuje i łatwo się obraża. Traktuje ją jako nieuzasadniony atak, arogancję, bezczelność. Powodem jest to, że krytyka dotyczy czegoś, co osoba chciałaby ukryć. Paradoksem jest, że jej wyolbrzymiona reakcja jeszcze bardziej uwydatnia to, od czego chciałaby odwrócić uwagę. Jej reakcja odsłania starannie skrywane niedoskonałości, które często są faktem. Przewrażliwienie odsłania ułomności. Matka może narzekać na zachowanie swojego 
dziecka do koleżanki, ale nikomu innemu nie wolno krytykować zachowań jej dziecka. Z kolei drażliwość może być mylona ze smutkiem. Jednak bardziej adekwatne jest skojarzenie z posępnością osoby, która okazuje nieustającą złość i tendencję do reagowania napadami gniewu i przesadną frustracją na drobnostki. $Z$ powodu drażliwości każde zachowanie osoby staje się negatywnym doświadczeniem dla niej i tych, z którymi przebywa. Taki niszczący charakter ma jej nieopanowanie, nietolerancyjność, złośliwe komentarze, zniecierpliwienie i okazywanie wzburzenia (por. https://pieknoumyslu.com/ depresja-smutek-drazliwosc/ [dostęp: 4.06.2020]). Interesujące studium przypadków wrażliwości i drażliwości na przykładzie środowiska uczonych przedstawił Zbigniew Drozdowicz (2018). Nadmierna wrażliwość staje się patologiczna, kiedy zniekształca życie osoby i upośledza jej funkcjonowanie w sferze osobistej i społecznej. Cnota, czyli usytuowanie pomiędzy skrajnościami, pozwala dostrzec swoją wyjątkowość i jednocześnie znać na tyle swoją miarę, by nie wpadać w samouwielbienie. Wywyższanie się ponad tę miarę powoduje, że krytyka odbierana jest jak kara i upokorzenie. Wrażliwość jest siłą człowieka, natomiast przewrażliwienie i drażliwość są oznaką jego słabości.

Niedomiarem wrażliwości jest niewrażliwość. W literaturze przedmiotu istnieje także odwołanie do zjawiska analfabetyzmu emocjonalnego, aleksytymii, anestetyki (por. Maruszewski, Ścigała 1998; Klimaszewska 2008; Kozak 2012; Szpunar 2017, 2018; Tomczok 2018). Analfabeta emocjonalny to osoba (dziecko, młodzież, dorosły), która nie ma wystarczająco ukształtowanych umiejętności związanych z emocjami do tego, by poznawać, rozumieć i radzić sobie z emocjami i uczuciami zarówno swoimi, jak i innych osób. Brakuje jej empatii, wrażliwości na cierpienie innych, chęci niesienia pomocy. Brak wrażliwości ogranicza umiejętności społeczne, m.in. bliskość niezbędną do tworzenia więzi miłości i przyjaźni. Skutkiem mogą być też skrajne poglądy, nękanie, rasizm, seksizm, narcyzm, obsesyjna potrzeba, by zawsze mieć rację. Brak lub niska możliwość radzenia sobie ze smutkiem, złością, strachem czy rozczarowaniem powoduje większą podatność na zaburzenia emocjonalne i umysłowe, np. depresje, chroniczne stany lękowe (https://pieknoumyslu. com/analfabetyzm-emocjonalny/ [dostęp: 8.06.2020]). Niewrażliwość dostrzegana jest także we współczesnej kulturze. Niemiecki 
filozof Wolfgang Welsch nazywa to zjawisko anestetyką, czyli niezdolnością do odczuwania, przeżywania i zinternalizowania znaczeń i to na wszystkich poziomach: od fizycznego otępienia po duchową ślepotę (Welsch 1998: 522). Chodzi o unikanie niepożądanych doświadczeń w skomplikowanej i zbyt złożonej rzeczywistości, przed którymi człowiek chroni się używając mechanizmów obronnych. Nadmiar doznawanych bodźców tak znacznie przekracza możliwość ich doznawania, że człowiek popada w swoistą apatię i wypalenie współczucia: „Anestetyka staje się zatem kulturową adaptacją do warunków nowoczesnego społeczeństwa” (Tomczok 2018: 188). Anestetyka może więc mieć konotacje pozytywne w obszarze, w którym ilościowy i jakościowy nadmiar doznań jest destrukcyjny dla funkcjonowania człowieka. Konsekwencją jest jednak chłód, zimno w wymiarze osobowościowym. Welsch wskazuje na coolness jako nową cnotę lat osiemdziesiątych, będącą znakiem nowej anestetyki: „chodzi o zobojętnienie, o brak doznań na narkotycznie wysokim poziomie pobudzenia" (Welsch 1998: 525). Nazwanie zanikania wrażliwości cnotą należy ująć w cudzysłów. Nawet jeśli pełni ono rolę mechanizmu obronnego, to skutkiem jest ograniczony dostęp do własnego wnętrza, a konkretnie - wgląd w życie emocjonalne (Maruszewski, Ścigała 1998: 134). Badania empiryczne dowodzą korelacji braku lub obniżonej wrażliwości z właściwościami ocenianymi negatywnie społecznie (por. Maruszewski, Ścigała 1998: 140), a nawet z przestępczością i psychopatią (por. Klimaszewska 2008: 69). Chłód i pustka emocjonalna stanowią przeszkodę $\mathrm{w}$ rozumieniu siebie i innych, prowadząc do patologicznych form rozwoju, m.in. egocentryzmu i narcyzmu.

Posiadane przez człowieka cnoty są ze sobą związane w takim znaczeniu, że posiadanie określonych cnót sprzyja kształtowaniu pozostałych (Jazukiewicz 2012: 170-171). Na przykład wrażliwość przyczynia się do poczucia odpowiedzialności za własne czyny, natomiast nadwrażliwość i moralna oschłość ograniczają jej zakres (Jazukiewicz 2012: 181-182). Z teoretycznej charakterystyki wrażliwości można wnioskować, że cnotami towarzyszącymi wrażliwości są szczerość, zaufanie, troska, empatia, życzliwość, uczciwość, sprawiedliwość, ciekawość i zdumienie (por. także Klimaszewska 2008: 70). 


\section{Empiryczna charakterystyka wrażliwości}

Badania empiryczne dotyczące wrażliwości ukierunkowane są na jej diagnozowanie oraz szukanie związków z innymi zjawiskami. Konstruowane są skale do pomiaru wrażliwości. Przykładem jest Skala Wrażliwości Empatycznej, będąca sparafrazowaniem Indeksu Reaktywności Interpersonalnej Marka H. Davisa (1999), której dokonali polscy psychologowie (Kaźmierczak, Plopa, Retowski 2007). Test składa się z trzech elementów: troski empatycznej i niepokoju osobistego (emocjonalny aspekt empatii) oraz wzięcia perspektywy (poznawczy aspekt empatii) (Kaźmierczak, Plopa, Retowski 2007: 14). Jest to propozycja badania wrażliwości jako jednej z istotnych umiejętności empatycznych, dzięki którym człowiek podnosi jakość swoich relacji interpersonalnych. Narzędzie może być wykorzystane do analizy interakcji społecznych, na przykład w obszarze życia rodzinnego i zawodowego.

Badania empiryczne dotyczące wrażliwości przynoszą ciekawe rezultaty, tym bardziej, że nie zawsze są one zgodne z codziennym wyobrażeniem dotyczącym zjawiska. Psycholog Joanna Klimaszewska (2008) zweryfikowała pozytywnie związek wrażliwości moralnej z wartościami hedonistycznymi, nasileniem cech narcystycznych i aleksytymią. Niepotwierdzona natomiast została hipoteza o związku satysfakcji z życia z wrażliwością moralną. Okazało się więc, że dla poczucia satysfakcji z życia nie jest konieczne realizowanie wartości związanych z wrażliwością moralną. Mając natomiast na uwadze ujemną korelację pomiędzy wrażliwością moralną a realizowaniem wartości hedonistycznych, badaczka uznała, że szukanie szczęścia przez współczesnego człowieka podąża w kierunku szukania przyjemności w wygodnym i dostatnim życiu:

Odwracanie się od norm i wartości moralnych, a w zamian kierowanie się ku przyjemnościom, to droga dość niebezpieczna w szukaniu satysfakcji życiowej. Nie tylko jest ona bowiem pełna pokus, ale także wiąże się z infantylnym systemem wartości, w którym o hierarchii decydują egoistyczne pobudki. Potwierdzeniem tego może być uzyskana w badaniu ujemna korelacja pomiędzy nasileniem cech narcystycznych a wrażliwością moralną. [...] Tak jak nasilenie cech narcystycznych, również aleksytymia utrudnia realizowanie wartości moralnych. Bez doświadczania i rozumienia emocji nie są bowiem możliwe empatia, współczucie, dostrzeganie drugiego człowieka (Klimaszewska 2008: 75). 
Badania naukowe wykazały, że osoby o wysokiej inteligencji charakteryzuje m.in. wysoka wrażliwość na stymulację (Limont 2014: 13-14). Osoby zdolne dostrzegają, czują i rozumieją więcej od osób o przeciętnych zdolnościach (por. Szpunar 2017: 131). Silnie emocjonalne osoby charakteryzuje zdolność do współodczuwania, współczucia, czułość w relacjach, ale też trudności w adaptacji do nowych warunków i subiektywne odczucie samotności. Właściwe jest dla nich silne przywiązywanie się do ludzi; liczba ich relacji społecznych jest niewielka, za to są one głębokie. Uznaje się, że wskaźnikami silnej emocjonalności są nieśmiałość i wstydliwość, ale też ekscytacja, euforyczność i długotrwałe pamiętanie emocji (por. Szpunar 2017: 131). Niemieccy psychologowie (Kroneisen, Heck 2020) wykazali, że im wyższa była emocjonalność badanych, tym wyższą przejawiali wrażliwość na normy moralne. Pozytywny związek dotyczył także wspomnianej wrażliwości z uczciwością i pokorą tych badanych.

Środowiskiem stosunkowo często poddawanym badaniu jest środowisko medyczne, ze względu na oczywiste znaczenie wrażliwości w rozumieniu sytuacji pacjenta. Przykładem jest opracowanie narzędzia badawczego do oceny wrażliwości etycznej oraz zdiagnozowanie jej wśród studentów medycyny Uniwersytetu w Toronto na czterech rocznikach (Hébert, Meslin, Dunn 1992). Badania wykazały, że wrażliwość etyczna nie była związana $\mathrm{z}$ wiekiem ani średnią ocen studentów. Wzrastała między pierwszym a drugim rokiem, a następnie spadała przez resztę studiów medycznych, tak że studenci czwartego roku identyfikowali mniej problemów moralnych niż osoby rozpoczynające naukę w uczelni medycznej. Studenci wyrażający wybór kariery medycyny rodzinnej przejawiali wyższą wrażliwość niż ich rówieśnicy. Badania przeprowadzone w Hiszpanii (Yuguero, Esquerda, Viñas, Soler-Gonzalez, Pifarré 2019) wśród studentów medycyny Uniwersytetu w Lleidzie potwierdziły wzrost wrażliwości etycznej między pierwszym i trzecim rokiem studiów, bez wzrostu w kolejnych latach; przebadano pięć kolejnych roczników. Nie znaleziono istotnych różnic między płcią. Badanie to wykazało natomiast korelację między wrażliwością etyczną a rozumowaniem moralnym i empatią. Znajomość tej relacji może być pomocna w opracowaniu bardziej optymalnego programu kształcenia, harmonijnie obejmującego rozwój etyczny i empatyczny oraz w zapobieganiu wypaleniu zawodowemu, 
którego rozpowszechnienie jest wysokie wśród pracowników służby zdrowia i jest odwrotnie skorelowane $\mathrm{z}$ empatią. W Japonii większość uczelni medycznych wprowadziła obowiązkowe kursy z zakresu etyki medycznej (Akabayashi, Slingsby, Kai, Nishimura, Yamagishi 2004: 1). Ich celem jest zwiększenie zrozumienia przez studentów norm etycznych i rozwiązywanie dylematów etycznych w warunkach klinicznych. Niestety, badania przeprowadzone w tym kraju również wykazały spadek wrażliwości moralnej studentów pod koniec studiowania (na szóstym roku studiów medycznych) (Akabayashi, Slingsby, Kai, Nishimura, Yamagishi 2004). Fakt ten potwierdzany empirycznie w poszczególnych krajach może wskazywać, że tradycyjne strategie nauczania mają tendencję do przeoczania kluczowych kompetencji rozpoznawania aspektów moralnych w niejednoznacznych sytuacjach klinicznych. Szwajcarscy badacze zwrócili uwagę, że moralne zachowanie nie znajduje odzwierciedlenia wyłącznie w wiedzy na temat etyki, ale także poprzez zwracanie uwagi na kompetencje psychologiczne. Oba aspekty należy uwzględnić w edukacji, w tym przypadku medycznej. Wspomniani autorzy, wykorzystując aktualną wiedzę z psychologii społecznej i moralnej, opracowali narzędzie badawcze oceniające wrażliwość na wartości w kontekście opieki klinicznej z uwzględnieniem kompetencji psychologicznych (Ineichen, Christen, Tanner (2017). Sprawdzono empirycznie także wpływ formy edukacji etycznej na wrażliwość moralną i osąd moralny: wzięto pod uwagę edukację etyczną opartą na debacie oraz w formie wykładowej; badania zostały przeprowadzone wśród studentów pielęgniarstwa w Republice Korei (Kim, Park 2019). Edukacja etyczna oparta na debacie była bardziej skuteczna w kształtowaniu moralnego osądu i zdolności do podejmowania etycznych decyzji w porównaniu z formą wykładową. Nie stwierdzono natomiast statystycznie istotnej różnicy pod względem wrażliwości moralnej.

Konstruowane są skale do pomiaru wrażliwości moralnej u dzieci i młodzieży. Przykładem jest tajska Skala Wrażliwości Moralnej (Tongsuebsai, Sujiva, Lawthong 2015). Operacjonalizacja wrażliwości moralnej doprowadziła do wyłonienia następujących elementów: (1) czytanie i wyrażanie emocji, (2) spojrzenie z perspektywy innych, (3) dbanie o znajomości z innymi osobami, (4) praca w przypadku różnic interpersonalnych i grupowych, (5) zapobieganie uprzedzeniom społecznym, (6) generowanie interpretacji i opcji 
oraz (7) określenie konsekwencji działań i opcji (Tongsuebsai, Sujiva, Lawthong 2015: 721).

Właściwości psychometryczne skali przetestowano w badaniu uczniów klas VII-IX. Natomiast badanie szwedzkich nastolatków między 15-20 rokiem życia dotyczyło sytuacji stosunkowo rzadko poddawanej empirycznej analizie. Celem badaczy (Thornberg, Jungert 2013) było bowiem sprawdzenie, w jaki sposób wrażliwość moralna w zastraszaniu, wycofanie moralne w zastraszaniu i samoobrona obrońcy były powiązane $\mathrm{z}$ różnymi zachowaniami obserwatora w zastraszaniu. Wyniki wykazały, że wrażliwość moralna w zastraszaniu była negatywnie związana $\mathrm{z}$ zachowaniami prowokującymi i pozytywnie związana z zachowaniami outsiderów i obrońców, mediowanymi przez moralne wycofanie się z prześladowań, co z kolei było pozytywnie powiązane $\mathrm{z}$ zachowaniami zastraszającymi i negatywnie związane $\mathrm{z}$ zachowaniami osób postronnych i obrońców. Dziewczęta w porównaniu z chłopcami miały wyższą wrażliwość moralną w zastraszaniu. $Z$ kolei polscy badacze Marzenna Magda-Adamowicz i Jacek Szmalec (2003) porównali wrażliwość moralną dzieci zdrowych i dzieci z upośledzeniem umysłowym w stopniu lekkim w młodszym wieku szkolnym. Wyodrębnili dwa komponenty wrażliwości moralnej: (1) poznawczy - dostrzeganie problemów moralnych, czyli rozumienie sytuacji, komunikatywność i reagowanie na innych oraz (2) emocjonalny - odczuwanie potrzeby rozwiązywania problemów moralnych, czyli wewnętrzną intencję ich rozwiązywania, motyw moralnych reakcji, stosunek do problemów moralnych i otoczenia (kontakty z rówieśnikami, reakcje na innych i wobec zajęć, współdziałanie) (Magda-Adamowicz, Szmalec 2003: 110). $\mathrm{Z}$ przedstawionych rezultatów badań wynika, że u badanych dzieci $\mathrm{z}$ upośledzeniem umysłowym $\mathrm{w}$ stopniu lekkim dominuje komponent emocjonalny nad poznawczym w rozwoju wrażliwości moralnej. U dzieci prawidłowo rozwiniętych jest odwrotnie: dominuje komponent poznawczy wrażliwości moralnej nad emocjonalnym. Wnioski cenne dla praktyki wychowawczej wynikają z badań dotyczących dzieci maltretowanych. Przeprowadzono je wśród chińskich studentów, sprawdzając związek między maltretowaniem w dzieciństwie a wrażliwością moralną (Xiang, Cao, Dong 2020). Stwierdzono, że maltretowanie w dzieciństwie może prowadzić do niemoralnych zachowań, a występowanie niemoralnych zachowań jest spowodowane 
głównie niską wrażliwością moralną. Wyniki badań mogą być pomocne w zrozumieniu indywidualnych zachowań moralnych i stanowić podstawę opracowania interwencji i łagodzenia negatywnych skutków maltretowania w dzieciństwie.

Stosunkowo nowym pojęciem w nauce jest wrażliwość duchowa. Jej koncepcja jest ujmowana w następujący sposób:

Koncepcja wrażliwości duchowej odnosi się do założeń humanistycznych, egzystencjalnych, ale także poznawczych teorii osobowości, podkreślających, że człowiek jest istotą intencjonalną, racjonalną i jest zaangażowany w realizację osobistych, znaczących celów. Takie podejście poszerza pojęcie duchowości, pozwala ująć je w naukowy sposób i umieszcza ją $\mathrm{w}$ istniejących, akceptowalnych ramach psychologii. $\mathrm{Ze}$ względu na wzajemnie powiązane umiejętności składające się na wrażliwość duchową człowiek może osiągać cele w życiu bardziej skutecznie, może również odnosić swoje codzienne życie do kontekstu uniwersalnych wartości oraz generować rozwiązania problemów i zadań życiowych, nadając im znaczenie (Kapała 2017: 11).

Autorskie badania dotyczące natury, struktury i roli wrażliwości duchowej w życiu człowieka, z jednoczesnym procesem skonstruowania narzędzia jej pomiaru - Inwentarza Wrażliwości Duchowej SSI - przeprowadziła polska psycholog Magdalena Kapała (2017). Wrażliwość duchowa została potraktowana jako atrybut każdego człowieka, potencjał, który można rozwijać, choć nie zawsze jest ona ujawniana. Są to kolejne badania empiryczne, z których wynika, że wrażliwość jest konstruktem hierarchicznym i wielowymiarowym, co wiąże się z potrzebą określenia jej składników. Wyróżniono następujące składniki: (1) holizm i harmonia, (2) mądrość, świadomość, sens, (3) religijność i wiara, (4) wrażliwość etyczno-moralna, (5) otwartość na drugiego człowieka, (6) zaangażowanie duchowe, (7) wrażliwość estetyczna (Kapała 2017: 17-18). Wyniki badań ujawniły zróżnicowanie poziomu wrażliwości duchowej względem wieku. Wrażliwość duchowa była najwyższa w grupie najstarszej (60+). Czynnik płci różnicował poziom wrażliwości duchowej i jej składników - kobiety uzyskiwały wyniki istotnie wyższe od mężczyzn. Okazało się jednak, że wraz z wiekiem różnice między płciami we wrażliwości duchowej maleją. $Z$ przeprowadzonych badań wynika też wniosek istotny dla praktyki wychowania i rozwoju, że rozwinięta wrażliwość duchowa wiąże się $\mathrm{z}$ wysokim poczuciem jakości życia i prawdopodobnie $\mathrm{z}$ poczuciem podmiotowości człowieka. Warto przypomnieć, że 
wspomniane wcześniej badania Klimaszewskiej (2008) nie potwierdziły związku satysfakcji z życia z wrażliwością moralną. Kategoria wrażliwości duchowej jest szersza: wrażliwość moralna stanowi jeden z jej komponentów. Wysokie poczucie jakości życia wymaga więc starań holistycznych w zakresie edukacji, wychowania i samowychowania, służących integralnemu rozwojowi człowieka, którego celem jest w pełni dojrzała osobowość.

Empiryczna charakterystyka wrażliwości wskazuje ją jako fenomen, który może być traktowany jako zasób służący do sprawnego funkcjonowania człowieka w życiu codziennym. Wnioski z badań empirycznych należy więc potraktować jako istotną przesłankę kształtowania wrażliwości w procesie edukacji i wychowania. Łącznie z przesłankami teoretycznymi mogą być wykorzystane do kreowania i korygowania praktyki wychowania.

\section{Wnioski dla praktyki kształtowania wrażliwości w procesie wychowania}

Wrażliwość należy współcześnie potraktować jako pedagogiczne wyzwanie $\mathrm{w}$ dwojakim wymiarze: $\mathrm{z}$ jednej strony należy ją kształtować, a $z$ drugiej - chronić przed tym, co może człowieka wrażliwego zgubić. Wrażliwość jawi się jako potencjał, który trzeba tak spożytkować, by nie była ona dla osoby ani społeczeństwa źródłem słabości, lecz siły (Rakoczy 2018: 143-144). Wiedza ekspercka poszczególnych nauk, teoretyczna i empiryczna, jest pomocna w wypracowywaniu praktyk codziennego życia, sprzyjających kształtowaniu i chronieniu wrażliwości. Wynikają z niej między innym następujące wskazania:

1. Wrażliwość jest jednym z cenniejszych zasobów, jakie może posiadać człowiek. Uzasadnione jest więc pozostawienie dla niej miejsca w programach edukacyjnych i wychowawczych oraz w procesie samowychowania. Jest to wręcz niezbędne wobec globalizacji, technicyzacji, informatyzacji życia, gdy nadmiar informacji niebezpiecznie zobojętnia i paraliżuje człowieka, niekoniecznie przyczyniając się do wzrostu jego wiedzy, a tym bardziej mądrości (por. Kamińska 2006/2007: 40). 
2. Istotą szczególnie wrażliwą, bo naturalnie bezbronną i podatną na wszelkie bodźce środowiska, jest dziecko. Jego wrażliwość powinna być przedmiotem zainteresowania środowisk $\mathrm{i}$ instytucji zaangażowanych $\mathrm{w}$ wychowanie: rodziny, przedszkola, szkoły. Należy jednak pamiętać, że wrażliwość ma być częścią doświadczenia dziecka, a nie tylko zadaniem wychowawczym lub terapeutycznym.

3. Wrażliwość jest nie tylko dana, ale i zadana. Badania zdecydowanie potwierdzają rolę edukacji i wychowania w kształtowaniu wrażliwości. Dzieci, które są nakłaniane do rywalizacji z rówieśnikami, mają zdecydowanie niższy poziom empatii od pozostałych. Do jej regresu, a nawet całkowitego wyeliminowania przyczyniają się także zaniedbania we wczesnym dzieciństwie i przemoc zarówno fizyczna, jak i psychiczna (Szpunar 2018: 18). Wrażliwość wspólwystępuje z empatią.

4. W dyskursie dotyczącym rozumienia i rozwoju wrażliwości dominuje komponent emocjonalny, pojawia się poznawczy i działaniowy, natomiast eliminowany jest etyczny. Socjalizacja i edukacja dziecka są procesami postępującej indywidualizacji: budowania poczucia własnej wartości, sprawczości, wyjątkowości, ale bez odniesienia do doświadczenia moralnego (Rakoczy 2018: 153). Kształtowanie wrażliwości powinno uwzględnić wzajemne przenikanie się jej wszystkich komponentów, by w pełni wpisać się w rozwój osoby.

5. Wrażliwość odgrywa istotną rolę w poznawaniu samego siebie: „Samopoznanie wymaga właśnie wrażliwości: pozwolenia sobie na uczucia, dostępu do świata wewnętrznego, co w konsekwencji prowadzi do zrozumienia siebie" (Cyrek 2018: 107).

6. Wrażliwość jest bezpośrednim stymulatorem twórczości, tym ważniejszym, im jej intensywność jest większa. Współwystępuje z twórczą wyobraźnią (Szpunar 2017: 125). Badania nad twórczością i uzdolnieniami o charakterze artystycznym pokazują, że osobowość twórcza ujawnia się już w wieku dziecięcym. Dzieci o skłonnościach artystycznych na ogół cechuje „wysoki poziom inteligencji, bogactwo wyobraźni, duża trwałość i chłonność uwagi, a także wysoki poziom emocjonalnej wrażliwości. Ich zachowania pełne są ekspresywności, spontaniczności i naturalności” (Szpunar 2017: 130). Dla rozważań 
o wychowaniu istotne jest też, że dzieci te mają jednocześnie „częstszą niż przeciętnie skłonność do urazów i kompleksów. Nierzadko są stygmatyzowane ze względu na nonkonformistyczne zachowania, wynikające $\mathrm{z}$ potrzeby samodzielności i odrębności, co przez dorosłych bywa odbierane jako przejaw arogancji i buty" (Szpunar 2017: 130).

7. Zastanawiająca jest koncepcja z zakresu społecznych aspektów technologii cyfrowych, która może być wykorzystana w praktycznym kształtowaniu wrażliwości. Według niej wrażliwość może być nie tylko mierzona na różnych skalach, ale także wspomagana przez nowe technologie:

Rodzi to wiarę (nie wiemy dziś, jak złudną), że dzięki tym pomiarom i wspomaganiu będziemy lepiej zarządzać naszą wrażliwością. Okazuje się, że w zależności od kształtu dobranego algorytmu technologie informacyjne mogą powodować większą lub mniejszą różnorodność doświadczanych stanów afektywnych. Spersonalizowany interfejs dostosowuje się do naszych emocji. Algorytm może nawet lepiej rozpoznawać nasze emocje niż ludzcy partnerzy. Programy stają się coraz bardziej „czuciowe". Wciąż doskonalone techniki rejestracji stanów afektywnych $[\ldots]$ pozwalają na zapis uczuć, interpretują nastroje [...] programy-detektory, które potrafią odkryć sarkazm, ironię i inne stany psychiczne, dzięki coraz lepszym programom przetwarzania języka naturalnego (Krzysztofek 2018: 37).

Wykorzystanie tej koncepcji jako przesłanki dla praktyki wychowania wymaga szczególnej mądrości wychowawcy. W technologicznym świecie jest bowiem możliwe uwrażliwienie użytkownika technologii, ale również jego odwrażliwienie. Reguły technologiczne, w których empatia jest całkowicie nieobecna, systematycznie wypierają reguły kulturowe, promujące wrażliwość (Pleszczyński 2018: 98). Wrażliwość jest atrybutem tego, co jest określane jako ludzkie (Cyrek 2018: 109). Programowanie maszyn na wrażliwość temu zadaniu nie dorówna. Można uznać, że człowiek ma do wyboru dwie możliwości. Po pierwsze, być niewrażliwym - uboższym, ale pozbawionym dylematów i cierpienia, a tym samym bardziej pasującym do wymagań współczesnego życia. Po drugie, być wrażliwym, ale narażając się na zranienia w wymiarze psychospołecznym (por. Koberda 2005). Refleksja pedagogiczna wnosi trzecią możliwość: bycia wrażliwym, ale $\mathrm{z}$ podjęciem pracy nad sobą $\mathrm{w}$ kierunku uczynienia wrażliwości swoją mocną stroną. Wymaga to wychowania rozumu, woli i uczuć. 
Wychowanie jest przestrzenią wspólnoty, dlatego powinno być także przestrzenią kształtowania i chronienia wrażliwości.

\section{Bibliografia}

Adorno T.W. (1984). Socjologia i dialektyka, [w:] Kryzys i schizma. Antyscjentystyczne tendencje w socjologii wspótczesnej, t. 2, wybór i wstęp E. Mokrzycki, Warszawa: PIW, s. 5-46.

Aron E.N. (2018). Wysoko wrażliwi. Jak funkcjonować w świecie, który nas przyttacza, przeł. J. Biecki, D. Rossowski, Łódź: Feeria Wydawnictwo Wydawnictwo JK.

Baczko B. (1964). Rousseau. Samotność i wspólnota, Warszawa: PWN.

Błaszczyk W. (2010). Wrażliwośc jako czynnik wptywu spotecznego na zmiany w organizacji, „Acta Universitatis Lodziensis. Folia Oeconomica”, nr 234, s. 93-100.

Chodkowska M. (2008). W poszukiwaniu perspektyw interdyscyplinarności teorii i praktyki pedagogicznej, ,Rocznik Pedagogiczny”, t. 31, s. 45-54.

Chojnacka M. (2018). (Od)czucie - przeczucie - wspótczucie. Wrażliwość egzystencjalna w filozofii Jean-Paula Sartre’a, „Kultura Współczesna”, $\mathrm{nr}$ 4(103), s. 114-125.

Cyrek B. (2018). Wrażliwośc wobec psychologizacji życia i kultury ekshibicjonizmu, „Kultura Wspó́czesna”, nr 4(103), s. 102-110.

Davis M.H. (1999). Empatia. O umiejętności wspótodczuwania, przeł. J. Kubiak, Gdańsk: Gdańskie Wydawnictwo Psychologiczne.

Dąbrowski K. (1975). Osobowość i jej ksztattowanie poprzez dezintegracje pozytywna, Warszawa: Polskie Towarzystwo Higieny Psychicznej.

Drozdowicz Z. (2018). Wrażliwoś́ i drażliwość uczonych, „Nauka”, nr 3, s. 51-65.

Hébert P.C., Meslin E.M., Dunn E.V. (1992). Measuring the Ethical Sensitivity of Medical Students: A Study at the University of Toronto, ,Journal of Medical Ethics", nr 18, s. 142-147.

Heraklit. (1992). Zdania, przeł. A. Czerniawski, Łódź: Wydawnictwo Biblioteka.

Jaspers K. (1993). Autobiografia filozoficzna, przeł. S. Tyrowicz, Toruń: Wydawnictwo Comer.

Jazukiewicz I. (2012). Pedeutologiczna teoria cnoty, Szczecin: Wydawnictwo Naukowe Uniwersytetu Szczecińskiego.

Jędraszewski M. (1994). W poszukiwaniu nowego humanizmu. J.-P. Sartre - E. Lévinas, Kraków: Wydawnictwo Naukowe Papieskiej Akademii Teologicznej.

Kabzińska I. (2017). Nadwrà̇liwi - kulturowi „odmieńcy”, „Etnografia Polska”, t. 61, z. 1-2, s. 83-103. 
Kamińska A. (2006/2007). Wrażliwość jako źródto rozumu filozoficznego, „Annales Universitatis Mariae Curie-Skłodowska. Sectio I: Philosophia-Sociologia”, t. 31/32, s. 39-48.

Kapała M. (2017). Duchowość jako niedoceniany aspekt psyche. Propozycja nowego ujęcia duchowości w psychologii - kategoria wrażliwości duchowej, „Annales Universitatis Mariae Curie-Skłodowska. Sectio J. Paedagogia-Psychologia”, t. 30, nr 1, s. 7-37.

Kapuściński R. (2007). Lapidaria, Warszawa: Wydawnictwo „Czytelnik”.

Kaźmierczak M., Plopa M., Retowski S. (2007). Skala Wrażliwości Empatycznej, „Przegląd Psychologiczny”, t. 50, nr 1, s. 9-24.

Kępiński A. (1977). Psychopatie, Warszawa: Państwowy Zakład Wydawnictw Lekarskich.

Klimaszewska J. (2008). Człowiek wrażliwy moralnie, czyli jaki?, „Studia Gdańskie. Wizje i Rzeczywistość”, t. 5, s. 67-76.

Kozak S. (2012). Patologia analfabetyzmu emocjonalnego. Przyczyny $i$ skutki braku empatii w rodzinie $i$ w środowisku pracy, Warszawa: Difin.

Krzysztofek K. (2018). Wrażliwośc zapisana w algorytmach? Między technomorfizacja cztowieka a antropomorfizacja maszyny, „Kultura Współczesna”, nr 4(103), s. 24-40.

Limont W. (2014). „Inny świat? Czy nieznany ich wtasny?”. Potencjat rozwojowy, wzmożona pobudliwość psychiczna a zdolności, „Psychologia Wychowawcza”, nr 5, s. 9-27.

Magda-Adamowicz M., Szmalec J. (2003). Wrażliwość moralna dzieci w wieku 7-10 lat prawidtowo rozwiniętych $i$ upośledzonych umystowo w stopniu lekkim (rekonesans z badań), „Rocznik Lubuski”, t. 29, cz. 2, s. 103-114.

Markowski M.P. (2010).Wrażliwość, interpretacja, literatura, „Teksty Drugie: Teoria Literatury, Krytyka, Interpretacja”, nr 1-2(121-122), s. 103-123.

Markowski M.P. (2013). Polityka wrażliwości, Kraków: Universitas.

Maruszewski T., Ścigała E. (1998). Emocje - aleksytymia - poznanie, Poznań: Wydawnictwo Fundacji Humaniora.

Pascal B. (2008). Myśli, przeł. T. Boy-Żeleński, Warszawa: Hachette Livre Polska.

Petitcollin Ch. (2019). Jak mniej myśleć. Dla analizujących bez końca i wysoko wrażliwych, przeł. K. Arustowicz, Łódź: Feeria Wydawnictwo.

Pleszczyński J. (2018). Aksjo- $i$ racjomorfizm a emocjonalna $i$ poznawcza wrażliwość, „Kultura Współczesna”, nr 4(103), s. 91-101.

Przybylski J. (1978). Pojęcie i struktura wrażliwości muzycznej, „Studia z Wychowania Muzycznego", nr 3, s. 45-71.

Rakoczy M. (2018). „To nie choroba czy zespót”. Dziecko i wspótczesne dyskursy wrażliwości, „Kultura Współczesna”, nr 4(103), s. 141-156.

Sand I. (2016), Wrażliwość - dar czy przeklenstwo?, przeł. E.M. Bilińska, Warszawa: MT Biznes.

Skarga B. (1997). Tożsamość i różnica, Kraków: Znak. 
Stoch M. (2016). Ekonomia wrażliwości a duch posthumanistyki, „Annales Universitatis Paedagogicae Cracoviensis. Studia de Cultura”, t. 8, nr 2, s. $130-140$.

Szpunar M. (2017). Wrażliwość (nie tylko) artystyczna, „Kultura i Społeczeństwo", nr 1, s. 123-134.

Szpunar M.(2018).(Nie)potrzebna wrażliwość, Kraków:Instytut Dziennikarstwa, Mediów i Komunikacji Społecznej Uniwersytetu Jagiellońskiego.

Thornberg R., Jungert T. (2013). Bystander Behavior in Bullying Situations: Basic Moral Sensitivity, Moral Disengagement and Defender Self-efficacy, "Journal of Adolescence”, t. 36, nr 3, s. 475-483.

Tischner J. (2011). Myślenie wedtug wartości, Kraków: Znak.

Tomczok P. (2018). Niewrażliwość cztowieka ekonomicznego, „Kultura Współczesna”, nr 4(103), s. 186-199.

Tongsuebsai K., Sujiva S., Lawthong N. (2015). Development and Construct Validity of the Moral Sensitivity Scale in Thai Version, „Procedia - Social and Behavioral Sciences", t. 191, s. 718-722.

Uniwersalny stownik jezzyka polskiego PWN. (2003). red. S. Dubisz, t. 4, Warszawa: Wydawnictwo Naukowe PWN.

Welsch W. (1998). Estetyka i anestetyka, [w]: Postmodernizm. Antologia przektadów, red. R. Nycz, Kraków: Wydawnictwo Baran i Suszczyński, s. $520-546$.

Wojtyła K. (1957). W poszukiwaniu podstaw perfekcjoryzmu w etyce, „Roczniki Filozoficzne”, t. 5, z. 4, s. 303-317.

Yuguero O., Esquerda M., Viñas J., Soler-Gonzalez J., Pifarré J. (2019). Ethics and Empathy: The Relationship between Moral Reasoning, Ethical Sensitivity and Empathy in Medical Students, „Revista Clínica Española”, t. 219 , nr 2, s. 73-78.

Zeff T. (2008). Być nadwrażliwym i przetrwać, przeł. E. Abłamowicz, Warszawa: Jacek Santorski \& Co Agencja Wydawnicza.

\section{Netografia}

Akabayashi A., Slingsby B.T., Kai I., Nishimura T., Yamagishi A. (2004). The Development of a Brief and Objective Method for Evaluating Moral Sensitivity and Reasoning in Medical Students, „BMC Medical Ethics”, t. 5, https://doi.org/10.1186/1472-6939-5-1 [dostęp: 4.05.2020].

Ineichen C., Christen M., Tanner C. (2017). Measuring Value Sensitivity in Medicine, „BMC Medical Ethics”, t. 18, https://doi.org/10.1186/ s12910-016-0164-7 [dostęp: 4.05.2020].

Kim W.-J., Park J.-H. (2019). The Effects of Debate-based Ethics Education on the Moral Sensitivity and Judgment of Nursing Students: A Quasi-experimental Study, „Nurse Education Today”, t. 83, https://doi.org/10.1016/j. nedt.2019.08.018 [dostęp: 4.05.2020]. 
Koberda P. (2005). Zabójcza wrażlizwość, http://www.racjonalista.pl/ kk.php/s,4482 [dostęp: 4.05.2020].

Kroneisen M.,Heck D.W.(2020). Interindividual Differences in the Sensitivity for Consequences, Moral Norms, and Preferences for Inaction: Relating Basic Personality Traits to the CNI Model, „Personality and Social Psychology Bulletin", t. 46, nr 7, https://doi.org/10.1177\%2F0146167219893994 [dostęp: 4.05.2020].

Xiang Y., Cao Y., Dong X. (2020). Childhood Maltreatment and Moral Sensitivity: An Interpretation Based on Schema Theory, „Personality and Individual Differences", t. 160, https://doi.org/10.1016/j.paid.2020.109924 [dostęp: 4.05.2020].

https://pieknoumyslu.com/analfabetyzm-emocjonalny/ [dostęp: 8.06.2020] https://pieknoumyslu.com/cytaty-dla-osob-wrazliwych/ [dostęp: 4.06.2020] https://pieknoumyslu.com/depresja-smutek-drazliwosc/ [dostęp: 4.06.2020]

\section{ADRES DO KORESPONDENCJI}

Dr hab. Iwona Jazukiewicz, prof. US

Uniwersytet Szczeciński

Instytut Pedagogiki

e-mail: i.jazukiewicz@gmail.com 